\title{
Awareness about disease and pulmonary rehabilitation in chronic obstructive pulmonary disease: A survey study
}

\author{
Kronik obstrüktif akciğer hastalığında hastalık ve pulmoner rehabilitasyon farkındalığı: \\ Bir anket çalışması
}
Erhan Uğurlu*, Hakan Alkan**, Göksel Altınışık*, Öznur Ataman**, Mukaddes Şener*, Esra Huriye Göçer**, Sibel Özkurt*, Fatma Evyapan*

*Pamukkale Üniversitesi Tıp Fakültesi, Göğüs Hastalıkları Anabilim dalı, Denizli

** Pamukkale Üniversitesi Tıp Fakültesi, Fizk Tedavi ve Rehabilitasyon Anabilim dalı, Denizli

\begin{abstract}
Purpose: Superiority of pulmonary rehabilitation $(P R)$ in patients with COPD have been entered the major guidelines of the disease and become gold standard of care in the management of COPD. Our aim is to evaluate the patients' awareness about their own illness and PR which supports behavioral interventions by encouraging exercise training, cooperative self-management depending on the patients themselves.

Materials and methods: The study was included 200 patients. Patients who are competent enough to complete the questionnaire and diagnosed as COPD according to Global Inıtıatıve for Chronic Obstructive Lung Disease(GOLD) criteria and at least 1 year on follow patients enrolled in the study. Questionnaire which is employed in our study is developed by a review of the current literature and consist of 3 parts. First part aims to investigate socio-demographics like age, gender, education and whereabouts. Second part (questions 1-9) evaluate the knowledge and awareness of COPD and 3rd part (10-22) investigate the awareness of PR.

Results: Among the patients $93 \%(n=186)$ were male and $7 \%(n=14)$ were female. Mean age was $65.11 \pm 10.00$ years. Mean duration of the disease was $7.8 \pm 6.69$ years. Correct answer rates to the questions "is there another treatment modality for COPD other than medication" and "have you ever heard a treatment named pulmonary rehabilitation" were $14.5 \%$ and $7.5 \%$, respectively.

Conclusion: We found that the awareness of pulmonary rehabilitation is very low. Therefore, in our opinion it is essential to find out new methods, novel strategies to increase the awareness of pulmonary rehabilitation in COPD patients.
\end{abstract}

Pam Med J 2018;11(2):151-156

Key words:Awareness, chronic obstructive pulmonary disease, pulmonary rehabilitation, lung

Özet

Amaç: KOAH tanısı olan hastalarda pulmoner rehabilitasyonun (PR) üstünlüğü hastalığın majör rehberlerine girmiştir ve KOAH' Iı hastaların standart bakımı olarak kabul edilmiştir. Bizde mevcut hastalıkları hakkında bilgi düzeylerini ölçmek ve eksersizeğitimleri, işbirlikçi özyönetimi teşvik eden programlarıyla davranışşal müdahaleleri destekleyen, pulmoner rehabilitasyonun hastalar tarafından bilinip bilinmediğini araştırmak istedik. Gereç ve Yöntem: Çalışmaya 200 hasta dahil edildi. Global Inıtıatıve for Chronic Obstructive Lung Disease (GOLD) kriterlerine göre KOAH tanısı almış, en az 1 yıldır takipte, anketteki soruları cevaplayabilecek fizik ve mental yeterli kapasiteye sahip olan hastalar çalışmaya dahil edildi. Çalışmada kullandığımız literatür derlenerek hazırlanan anket, 3 bölümden oluşmaktadır. Birinci bölüm hastanın yaş, cinsiyet, eğitim düzeyi, yaşadığı yer gibi sosyodemografik özellikleri sorgulayan bölümdür. İkinci bölüm (1-9 arası sorular) KOAH bilgi düzeyi ve farkındalığını, üçüncü bölüm (10-22 arası sorular) ise PR farkındalığını değerlendiren bölümdür.

Bulgular: Hastaların \%93 $(n=186)^{\prime}$ ü erkek, \%7 $(n=14)$ kadındı. Ortalama yaşları ise $65.11 \pm 10.00$. Ortalama

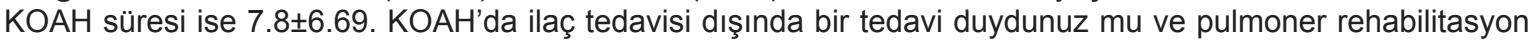
isimli bir tedavi duydunuz mu sorularına verilen doğru cevap oranı $\% 14.5$ ve $\% 7.5$ dur.

Sonuç:KOAH hastalarında pulmoner rehabilitasyonun farkındalığını oldukça düşük bulduk. Bu nedenle bu hastalarda farkındalığı artırmak için yeni stratejiler, yeni methodlar geliştirilmelidir.

Pam Tıp Derg 2018;11(2):151-156

Anahtar sözcükler:Farkındalık, kronik obstrüktif akciğer hastalığı, pulmoner rehabilitasyon, akciğer

Erhan Uğurlu

Yazışma Adresi: Pamukkale Üniversitesi Tıp Fakültesi, Göğüs Hastalıkları Ana bilim dalı, Denizli.

e-mail: drerhan724@gmail.com

Gönderilme tarihi: 24.10.2017

Kabul tarihi: 26.12.2017 


\section{Introduction}

Chronic Obstructive Pulmonary Disease (COPD) is a common, preventable, and manageable disease process that is characterized by progressive persistent airflow restrictions and is related to increased chronic inflammatory reaction of the airways and lungs against harmful gases and particles [1]. COPD is the 4th most common cause of death worldwide and it is expected to move up to 3rd place by the year 2020. Hospitalization rates are also increasing every other day [2-4].

Superiority of pulmonary rehabilitation (PR) in patients with COPD have been included in the major guidelines of the disease and becomes the gold standard for care in the management of COPD [5]. PR helps in dealing with the problems encountered during the management of COPD, like peripheral muscle loss and dysfunction, intolerance of physical effort, anxiety and depression, and behavior problems like sedentary lifestyle and ceasing prescribed medications [6]. PR does not directly improve static measurements of pulmonary function but improves quality of life by reducing dyspnea and increasing physical effort tolerance. PR reduces the frequency of COPD exacerbations and hospitalization rates especially when performed before acute exacerbations [6].

Our aim is to evaluate patients' awareness of their own illness and PR, which supports behavioral interventions byencouraging exercise training and cooperative self-management depending on the patients themselves.

\section{Methods}

Approval was obtained from the University Ethical Board on Human Studies with the registration number 60116787-010/13996. Patients, who have COPD diagnosis (regardless of their stage) according to GOLD (Global Initiative for Chronic Obstructive Lung Disease), at least one year in follow-up and no professional training in pulmonary rehabilitation and about their diseases previously, were included in the study. Those who were not able to complete the questionnaire because of a mental or general condition impaired, those who said they did not understand the questions in the questionnaire, those who received non-invasive mechanical ventilation therapy and severe hypoxic patients were excluded from the study.
The questionnaire used in this study was developed by a review of the current literature and consists of three parts $[3,7,8]$ (supplementary material). The first part of the questionnaire indicates sociodemographic characteristics. The second part (1-9 questions) was asked to determine the COPD awareness of patients and it was taken from the questionnaire for the assessment of asthma and COPD awareness in Turkey (GARD Turkey Project National Control Program for Chronic Airways Diseases) [8]. The validity and reliability of this questionnaire is not specified in the study. The third part of our questionnaire (questions 10-22) was asked to determine the patients' awareness of pulmonary rehabilitation and was taken from a questionnaire study conducted in India [3]. This questionnaire has validity and reliability. In addition, the questions in these two surveys were compared and found to be consistent with the Bristol COPD Knowledge Questionnaire (BCKQ) [7].

The questions were crafted to be as simple and short as possible to express clarity and compatibility. To reduce misunderstanding and confusion, most answers consisted of three choices: "yes", "no" and "I don't know". "Yes" answers were evaluated as being correct, while "no" and "I don't know" answered were accepted as incorrect answers. A large majority of the questionnaires (approximately 90\%) were filled by a specialist in a polyclinic condition about a 15-minute face-to-face interview with COPD patients who came to polyclinic. The remaining part was applied to patients with COPD who were still able to complete the questionnaire at the service by the same specialist. The physician was instructed not to make any comment about the questions or answers, including giving any clues about the correct answer.

A power analysis demonstrated a $90 \%$ power with $95 \%$ confidence if the study group consisted of 200 patients. The Statistical Package for the Social Sciences (SPSS) version 16.0 was employed for statistical analysis. Frequency (n), percentage (\%), mean and standard deviation were used as descriptive statistics.

\section{Results}

A total of 200 patients with COPD completed the questionnaire. Among the patients, 93\% $(n=186)$ were male and $7 \%(n=14)$ were female. 
The mean age was $65.11 \pm 10.00$ years and the mean duration of the disease was $7.8 \pm 6.69$ years. Among the patients, $6.5 \%(n=13)$ had no education, $71.5 \%$ had primary school education, $12 \%(n=24)$ had high school education, and $10 \% \quad(n=20)$ had higher education. Study population was composed of patients residing in urban $48.5 \%,(n=97)$ and rural $51.5 \%,(n=103)$ regions.

In the second part of the questionnaire, the correct response rates to the questions for measuring the awareness of diseases, which is COPD a lung disease, role of smoking, other risk factors, diagnostic tests, effect of ceasing smoking are $83 \%, 81.5 \%, 83.5 \%, 71 \%$ and $86 \%$, respectively (Figure 1 ).

Results of disease awareness are shown in Figure 1.

Results of pulmonary rehabilitation awareness are shown in Figure 2.

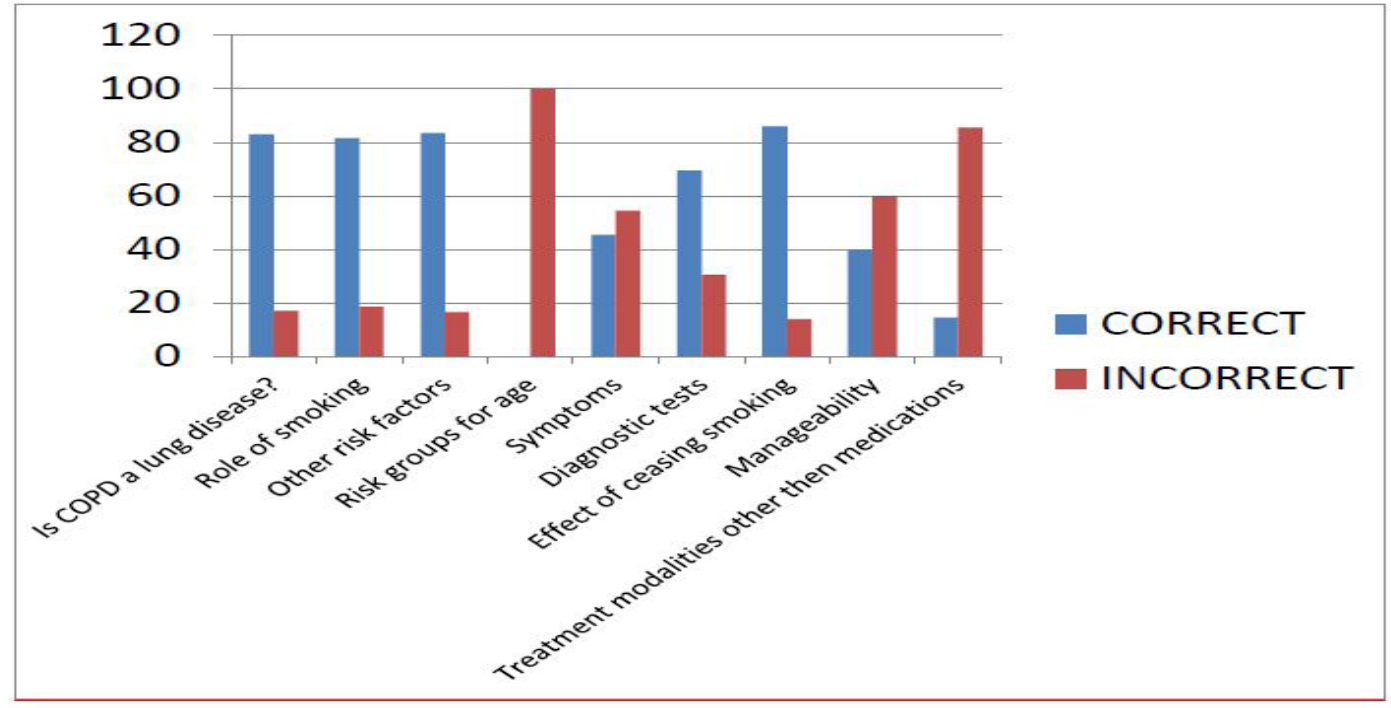

Figure 1. Results of disease awareness

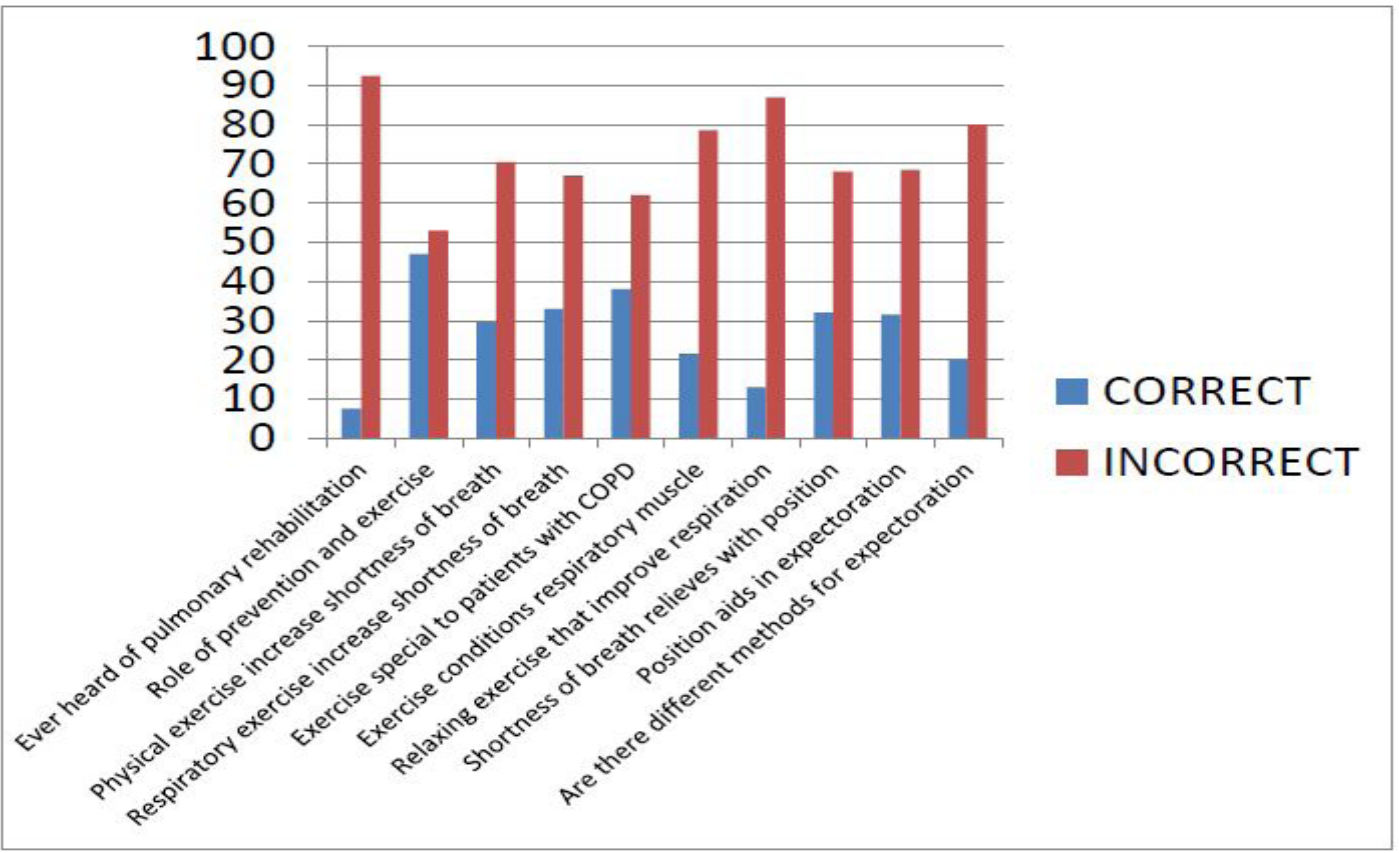

Figure 2. Results of pulmonary rehabilitation awareness 


\section{Discussion}

We found our COPD patients' awareness of pulmonary rehabilitation to be very low when we had a relatively high awareness of their disease.

As shown in Figure 1, correct answer rates to the questions of which organ is involved, the effect of smoking, the effect of other risk factors, and the effect of ceasing smoking are $83 \%, 81.5 \%, 83.5 \%$, and $86 \%$, respectively. A similar study of Indian participants by Raksha et al. [3] reported true answer rates in 282 patients with COPD to the same questions as $42.6 \%, 46.5 \%$, and $34.8 \%$, respectively, while the effect of ceasing smoking was not investigated. In addition, recent advances in our country that resulted in prohibition of smoking in the public places and public announcements about the hazards of smoking like lung cancer and COPD may also have contributed to these results. In a study by Yıldız et al. [8], who conducted the Global Alliance Against Chronic Respiratory Diseases (GARD) project among 8527 subjects, the true response rates to these four questions were $49.6 \%, 51.1 \%, 49.3 \%$, and $48 \%$, respectively. These lower rates may be related to the fact that the study was conducted in the normal population, not in patients with COPD.

Among our patients, the question of "which age group is mostly affected by COPD" elicited the response "all age groups" from $80.5 \%$ of the respondents. Yıldız et al. [8] received the same answer from $24.6 \%$ of their patients, but the presence of an "I don't know" option in the questionnaire may influence the results because $49.3 \%$ of the patients marked this option.

The query of "what are the complaints of a patient with COPD" yielded a $45.5 \%$ correct answer rate, with $43.5 \%$ have chosen "shortness of breath". Meanwhile, coughing and sputum production was indicated by $5 \%$ of the participants, which may be attributable to the perception that coughing and sputum are ordinary complaints or are due to smoking itself. In a French study by Philippe et al. [9], 67.1\% of the participants responded to the "what is the cause of daily coughing, sputum, and shortness of breath" question with "smoking".
In a Japanese study by Masaharu et al. [10] about the awareness of COPD and impact of COPD educations on the awareness, $87 \%$ of the participants responded to the question "coughing, sputum, and shortness of breath are symptoms of early stage COPD or not" with the correct answer. Our lower rates may be secondary to questioning types.

The query "is COPD a treatable disease" yielded $40 \%$ true response rate in our study. Yildız et al. [8] noted $25.2 \%$ correct answers in this query, while Masaharu et al. [10] found an $85.8 \%$ correct answer rate. Similar to our results, Rashka et al. [3] reported a $51.1 \%$ correct answer rate to the same query. The lower rates of Yıldız et al. [8] might be attributed to the fact that the questionnaire was applied to a heterogeneous sample of the general population, not only to patients with COPD. The higher correct answer rates of Masahura et al. [10] may be due to the mean patient education duration of six years.

In our study, the correct answer rates to the questions "is there another treatment modality for COPD other than medication" and "have you ever heard a treatment named pulmonary rehabilitation" were $14.5 \%$ and $7.5 \%$, respectively. COPD awareness of patients about the pulmonary rehabilitation was low, as we hypothesized. Existing data about the awareness of pulmonary rehabilitation is limited. Rashka et al. [3] found a $25.14 \%$ awareness rate in their study. In a multicenter study containing 12 centers with a Cardiopulmonary Rehabilitation (CPR) unit and 727 participants, Sarıkaya et al. [11] found a $79.3 \%$ awareness rate, although knowledge was not comprehensive. Among the participating health care providers, 39.2\% received education about CPR in some part of their professional lives. There is about $80 \%$ awareness of pulmonary rehabilitation, even though almost half of the workers are trained persons in the area of health. Healthcare professionals, who need to provide awareness about pulmonary rehabilitation in patients, are not aware of the situation. As a result, patients are unaware of pulmonary rehabilitation, but healthcare professionals who provide this awareness are not adequately informed about pulmonary rehabilitation. 
In the third part of the questionnaire covering the content of PR, correct answers were lower than incorrect answers in all the queries. As $92.5 \%$ of the patients were ignorant of $P R$, it is not surprising that they were not aware of the content. Most of the patients chose "I don't know" as a response to this query. Almost half of the patients believed that activities like physical and respiratory exercise, cycling, swimming, and jogging have detrimental effects.

The correct response rates given to the second part of the questionnaire range between $40 \%$ and $86 \%$, and the correct answer rates given to the third part vary between $7.5 \%$ and $47.5 \%$. Although these ratios may be relatively good at the point of awareness of their illness, the awareness of pulmonary rehabilitation is extremely poor. The role of $P R$ in the management of COPD is indisputable [12]. It improves quality of life and exercise capacity, while also reducing dyspnea [13]. It is alarming that such an effective treatment modality is not well recognized by the patients. To increase awareness, education programs must be initiated to educate health care providers. Mandatory public announcements and promotions must be employed as in the campaign against smoking. Also, PR education must be mandatory for the pulmonology residents during an education period that will take care of patients with COPD. Leaflets about PR can also be distributed by the family physicians to the patients.

The study has a few limitations. As a tertiary center, most of our patients have advanced or most severe COPD. Most hospitalized patients are excluded from the study as they are dependent on invasive or non-invasive mechanical ventilators or have severe hypoxia, and their insufficient mental and physical status would not allow them to respond to the questions. Patients admitted to the outpatient clinic were also excluded because most of them had poor compliance and cooperation with advanced disease and severe hypoxia. Generally, patients with mild to moderate disease were enrolled in the study. The second major limitation of this study is the lack of validity and reliability of this questionnaire.
This is the first study to evaluate the awareness of PR among patients with COPD conducted in our country, and to the best of our knowledge, the second study in the English language literature. A further randomized study with the participation of multiple centers to evaluate the level of awareness is necessary. We found the awareness of pulmonary rehabilitation very low in COPD patients. Necessary measures must be taken in this regard. Patients should be informed first after health workers have been trained.

Conflict of interest:The authors declared no conflict of interest.

\section{References}

1. Vestbo J, Hurd SS, Agustí AG, et al. Global strategy for the diagnosis, management, and prevention of chronic obstructive pulmonary disease. Am J RespirCrit Care Med 2013;187:347-65.

2. Hurd S. The impact of COPD on lung health worldwide epidemiology and incidence. Chest 2000;117:1-4.

3. Thakrar R, Alaparthi GK, Kumar SK, Vaishali K, Zulfeequer CP, Aanad R. Awareness in patients with COPD about the disease and pulmonary rehabilitation: A survey. Lung India 2014;31:134-138

4. Global Initiative for Chronic Obstructive Lung Disease (GOLD). Global strategy for the diagnosis, management, and prevention of chronic obstructive pulmonary disease: updated2014.http://www. goldcopd.org/uploads/users/files/GOLD_Report2014_ Feb07.pdf)

5. Spruit MA, Singh SJ, Garvey C, et al. An official American Thoracic Society/European Respiratory Society statement: key concepts and advances in pulmonary rehabilitation. Am J RespirCrit Care Med 2013;188:13-64.

6. Nici L, ZuWallack RL. Pulmonary rehabilitation future directions. Clin Chest Med2014;35:439-444

7. White R, Walker P, Roberts S, Kalisky S, White P. Bristol COPD Knowledge Questionnaire (BCKQ): Testing what we teach patients about COPD. ChronRespir Dis 2006;3:123-131.

8. Yıldız F, BingölKarakoç G, ErsuHamutçu R, Yardım N, Ekıncı B, Yorgancıoğlu A. The evaluation of asthma and COPD awareness in Turkey (GARD Turkey Project-National Control Program of Chronic Airway Diseases. TuberkToraks2013;61:175-182.

9. Carré PC, Roche N, Neukirch F, et al. The effect of an information leaflet upon knowledge and awareness of COPD in potential sufferers. Respiration 2008;76:5360. 
10. Asai M, Tanaka T, Kozu R, Kitagawa C, Tabusadani M, Senjyu H. Effect of a Chronic Obstructive Pulmonary Disease (COPD) intervention on COPD awareness in a regional city in Japan. Intern Med 2015;54:163-169.

11. Sarıkaya $S$, Tur BS, Kurtaiş $Y$, et al. The awareness of physicians and allied health professionals about cardiopulmonary rehabilitation: A cross-sectional survey study. Turk J Phys Med Rehab 2014;60:19-24.

12. Rugbjerg $M$, lepsen UW, Jørgensen KJ, Lange P. Effectiveness of pulmonary rehabilitation in COPD with mild symptoms: a systematic review with meta-analyses. Int $\mathrm{J}$ Chron Obstruct Pulmon Dis 2015;10:791-801.

13. Lacasse Y, Martin S, Lasserson TJ, Goldstein RS. Meta-analysis of respiratory rehabilitation in chronic obstructive pulmonary disease. A Cochrane systematic review. EuraMedicophys 2007;43:475-485. 